\title{
Evaluation of Chemical, Functional and Sensory Properties of Flour Blends from Sorghum, African Yam Bean and Soybean for Use as Complementary Feeding
}

\author{
Bello Florence Abolaji1, *, Edeke Joy Edeke', Sodipo Mopelola Ajoke ${ }^{2}$ \\ ${ }^{1}$ Department of Food Science and Technology, University of Uyo, Uyo, Nigeria \\ ${ }^{2}$ Department of Food Science and Technology, Federal University of Technology, Akure, Nigeria
}

Email address:

florenceabello@uniuyo.edu.ng (B. F. Abolaji)

${ }^{*}$ Corresponding author

\section{To cite this article:}

Bello Florence Abolaji, Edeke Joy Edeke, Sodipo Mopelola Ajoke. Evaluation of Chemical, Functional and Sensory Properties of Flour Blends from Sorghum, African Yam Bean and Soybean for Use as Complementary Feeding. International Journal of Food Science and Biotechnology. Vol. 4, No. 3, 2019, pp. 74-81. doi: 10.11648/j.ijfsb.20190403.13

Received: September 5, 2019; Accepted: September 27, 2019; Published: October 11, 2019

\begin{abstract}
The use of sorghum, African yam bean and soybean flour blends in the formulation of low cost, nutritive complementary diet was studied. The blends of sorghum, African yam bean and soybean flour considered were coded as SASA, SASB, SASC and SASD for 90:5:5, 80:10:10, 70:15:15, 60:20:20, respectively. The blends were compared with a commercial weaning diet (cerelac) coded as CTR and 100\% sorghum flour (SG). The formulated diets were analysed for their proximate, mineral, anti-nutritional, functional and sensory properties using standard methods. The results showed that there were increases in the proximate and mineral compositions, with a decrease in anti-nutrient content as the substitution level increased. Sensory evaluation of the sample showed that the SASA after reconstitution with hot water was well accepted by the panelists, though the panelists preferred SG and CTR, this could be explained that the panelists are more familiar with them compared to the new formulations. As indicated by the results, food-to-food supplementation would be a suitable form of home fortification for regions where protein energy malnutrition is prevalent.
\end{abstract}

Keywords: Sorghum, Substitution, African Yam Bean, Complementary Food, Reconstitution

\section{Introduction}

Complementary feeding is necessary for both nutritional and developmental reasons, and is an important stage in the transition from milk feeding to family foods. It is defined as the process starting when breast milk alone is no longer sufficient to meet the nutritional requirement of infants so that other foods and liquids are needed, along with breast milk. In developing countries like Nigeria complementary foods are mainly based on starch tubers like cocoyam, sweet potatoes or on cereals like sorghum, maize or millet. Children are normally given these staples in the form of porridge [1]. There is a prevailing problem of protein-energy malnutrition in infants during the period of complementary feeding which can be attributed to the consumption of much cereal based pap and porridges, thus the need for incorporation of legumes in increasing the protein content of cereal based foods. The development of nutritious complementary foods from local and readily available raw materials has received considerable attention in many developing countries [2].

Sorghum (Sorghum bicolor [L] Moench) is one of the most underutilized crops in the semi-arid tropics of Asia and Africa. It is the principal source of energy, protein, vitamins and minerals for millions of the poorest in these regions. Sorghum products are deficient in essential amino acids such as lysine, methionine, tryptophan and the presence of antinutritional factors such as tannin and phytate which limit their nutritional value [3]. As cereals are generally low in protein, supplementation of sorghum with locally available legume that is high in protein increases protein content of cereal-legume blends [4]. African yam bean (Sphenostylis stenocarpa) is one of the lesser known edible grain legumes that is predominantly cultivated and utilized in Africa [5], 
and its protein is made up of over $32 \%$ of essential amino acids with lysine and leucine being predominant [6]. It ranks well among neglected crops and can contribute to food security if its genetic resources are saved for utilization in breeding and improvement [7]. Soybean (Glycine max) is a legume species native to East Asia, widely grown for its edible bean which has numerous uses. Soybeans are included in the category of oilseed, which is a generic reference to crops with seeds that can produce edible and/or non-edible oil in economic quantities. It has a protein content of approximately $43 \%$ [8] and about 3\% lecithin which are helpful for the brain development especially of infants. Soybean has essential minerals such as calcium, phosphorous and vitamins $\mathrm{A}, \mathrm{B}, \mathrm{C}$ and $\mathrm{D}$ and other health promoting compounds [1]. Therefore, the objective of the study was to determine the nutritional, anti-nutritional and functional properties of sorghum-based complementary flour supplemented with African yam bean and soybean flour blends as well as sensory properties of the formulated diets.

\section{Materials and Methods}

\subsection{Material Procurement}

Sorghum, African yam bean and soybean seeds were procured from Itam market in Uyo Local Government and Siangaran market in Ini Local Government Area.

\subsection{Sample Preparation}

\subsubsection{Processing of Fermented Sorghum Flour}

Fermented sorghum flour was produced using the method of [9]. The grains were cleaned and steeped in water $(1: 3)$ to encourage fermentation which was for $72 \mathrm{~h}$. The fermented sorghum was then washed and dried in a hot air oven (Model PP 22 US, Genlab, England) at $70^{\circ} \mathrm{C}$ for $24 \mathrm{~h}$. It was dry milled (Model Corona) and sieved $(500 \mu \mathrm{m}$ mesh of pore size) to obtain fine sorghum flour, packaged in an airtight container.

\subsubsection{Processing of Sprouted African Yam Bean Flour}

The cleaned African yam bean was steeped in water (1:3) at room temperature for a period of $24 \mathrm{~h}$ to achieve easy germination. The beans were spread on a jute bag for germination at room temperature for $72 \mathrm{~h}$ after which the beans was dehulled manually. Thereafter the dehulled beans were washed with tab water to remove the outer coat. The beans were oven dried (Model PP 22 US, Genlab, England) at $70^{\circ} \mathrm{C}$ for $24 \mathrm{~h}$, after which it was dry milled (Model Corona) into flour. It was sieved $(500 \mu \mathrm{m}$ mesh of pore size) and packaged in an airtight container according to the method described [10].

\subsubsection{Processing of Soybean Flour}

One (1) kg of soybean was sorted, washed and blanched at $85^{\circ} \mathrm{C}$ using a water bath (Model Griffin and George BJL$400-110 \mathrm{~F}$ ). It was then soaked in $3 \mathrm{~L}$ of water for $24 \mathrm{~h}$ with a change of water after every $6 \mathrm{~h}$ to prevent fermentation after which it was dehulled, washed and oven dried (Model PP 22
US, Genlab, England) at $50^{\circ} \mathrm{C}$ for $48 \mathrm{~h}$. It was dry milled (Model Corona), sieved $(500 \mu \mathrm{m}$ mesh of pore size) into fine flour and packaged in an airtight container as described [11].

\subsubsection{Formulation of Sorghum, African Yam Bean and Soybean Flour Blends}

The blending of the flour was done using a mechanical blender (Model Philips HR 7762-90, China) to obtain uniform blends. The flour blends were in the proportion 100:0:0, 90:5:5, 80:10:10, 70:15:15 and 60:20:20 designated as SG, SASA, SASB, SASC and SASD, respectively, as shown in Table 1. These samples were packaged in airtight container at room temperature while the commercial formula (cerelac) was used as control.

Table 1. Sample Formulation.

\begin{tabular}{llllll}
\hline Sample code & SG & SASA & SASB & SASC & SASD \\
\hline Sorghum flour & 100 & 90 & 80 & 70 & 60 \\
African yam bean flour & 0 & 5 & 10 & 15 & 20 \\
Soybean flour & 0 & 5 & 10 & 15 & 20 \\
\hline
\end{tabular}

\subsection{Proximate Analysis of Complementary Flour Blends and Commercial Formula}

Moisture, ash, crude protein, crude fat and crude fibre contents of the complementary flour blends were carried out. Total carbohydrate was determined by difference method and was quantified based on the percentage difference of the other proximate indexes as follows: \%carbohydrate $=100$ $(\%$ moisture $+\%$ ash $+\%$ crude protein $+\%$ crude fat $+\%$ crude fibre). The total energy was calculated using Atwater factor using the formula: energy value $=(\%$ crude protein $\times 4)+$ $(\%$ crude fat $\times 9)+(\%$ carbohydrate $\times 4)$ according to the method described [12].

\subsection{Determination of Mineral Content of Complementary Flour Blends and Commercial Formula}

Dry digestion method was used. The sample was air dried for $1 \mathrm{~h}$ and oven dried at $105^{\circ} \mathrm{C}$ for $1 \mathrm{~h}$. Five (5) $\mathrm{g}$ of sample was weighed into a crucible and digested with $0.3 \mathrm{ml}$ of $\mathrm{HNO}_{3}$, made up to $100 \mathrm{ml}$ with water in a volumetric flask and heated up to $100^{\circ} \mathrm{C}$ till a white fume was liberated. It was cooled, filtered and the solution was made up to $100 \mathrm{ml}$ and used for further determination of mineral. Filtrate from each sample was analyzed for zinc, iron, calcium and magnesium contents using an atomic absorption spectrophotometer (Thermoelemental UNICAM 969 model) with standard wavelengths. Sodium was analysed using atomic emission spectrophotometer. The real values were extrapolated from the respective standard curves as described [12].

\subsection{Determination of Anti-nutritional Factors of Complementary Flour Blends and Commercial Formula}

Determination of total oxalate, phytate, hydrogen cyanide using alkaline filtration and tannin were determined using the method [12-15]. 


\subsection{Determination of Functional Properties of Complementary Flour Blends and Commercial Formula}

Bulk density, water absorption capacity, oil absorption capacity, gelatinization temperature and swelling index were determined following the method described $[13,16]$.

\subsection{Sensory Evaluation of the Gruel}

The complementary flour blends were prepared into gruel by reconstituting different proportions of sorghum-African yam bean-soybean flour blends with boiling water. During preparation, $60 \mathrm{~g}$ of each sample was suspended with $100 \mathrm{ml}$ of potable water in a small plastic bowl. After that, $60 \mathrm{ml}$ of boiling water was added to each of the suspended sample to produce hot gruel. Sensory characteristics of the coded gruel were evaluated for different sensory attributes by twenty (20) semi-trained panelists drawn from the Department of Food Science and Technology, University of Uyo of whom five (5) were nursing mothers. All the panelists were briefed before the commencement of the evaluation process. Sensory attributes evaluated were appearance, taste, flavour, mouth feel, consistency and general acceptability. The rating was on a nine- point hedonic scale ranging from 1 (dislike extremely) to 9 (like extremely). All panelists were regular consumers of sorghum gruel, water at room temperature was provided to rinse the mouth between evaluations as described [17].

\subsection{Statistical Analysis}

All the data were subjected to statistical analysis using Analysis of Variance (ANOVA). The means were then separated with the use of Duncan's new multiple range test using the Statistical Package for the Social Sciences (SPSS) 21 software.

\section{Results}

\subsection{Proximate Composition and Energy Value of Complementary Flour Blends and Commercial Formula}

The results of proximate composition and energy value of sorghum, African yam bean and soybean complementary flour blends and the commercial formula (cerelac) were presented in Table 2. The moisture content of all the samples was not significantly $(\mathrm{p}>0.05)$ different from CTR (commercial formula), it ranged from 3.93-5.03\%. Ash content was significantly $(\mathrm{p}<0.05)$ different from CTR, it ranged from $2.65 \%$ (SG) to $3.35 \%$ (SASB) while the CTR was $2.03 \%$. The formulated samples had ash content higher than the CTR.

Table 2. Proximate composition (\%) and energy value (kcal) of complementary flour blends and commercial formula.

\begin{tabular}{|c|c|c|c|c|c|c|}
\hline \multirow{2}{*}{ Parameter } & SG & SASA & SASB & SASC & SASD & CTR \\
\hline & $(100: 0: 0)$ & (90:5:5) & (80:10:10) & $(70: 15: 15)$ & (60:20:20) & (Control) \\
\hline Moisture & $3.93 \pm 0.32^{\mathrm{a}}$ & $4.95 \pm 0.71^{\mathrm{a}}$ & $4.53 \pm 0.39^{\mathrm{a}}$ & $4.98 \pm 0.25^{\mathrm{a}}$ & $5.03 \pm 0.04^{\mathrm{a}}$ & $4.98 \pm 0.04^{\mathrm{a}}$ \\
\hline Ash & $2.65 \pm 0.07^{\mathrm{c}}$ & $2.98 \pm 0.11^{\mathrm{ab}}$ & $3.35 \pm 0.21^{\mathrm{a}}$ & $3.08 \pm 0.04^{\mathrm{ab}}$ & $2.88 \pm 0.04^{\mathrm{bc}}$ & $2.03 \pm 0.04^{\mathrm{d}}$ \\
\hline Crude protein & $4.39 \pm 0.01^{\mathrm{f}}$ & $5.06 \pm 0.07^{\mathrm{e}}$ & $9.26 \pm 0.03^{\mathrm{c}}$ & $11.03 \pm 0.02^{\mathrm{b}}$ & $14.85 \pm 0.05^{\mathrm{a}}$ & $5.83 \pm 0.04^{\mathrm{d}}$ \\
\hline Crude fat & $3.70 \pm 0.14^{\mathrm{d}}$ & $4.18 \pm 0.04^{c}$ & $4.70 \pm 0.00^{\mathrm{b}}$ & $4.85 \pm 0.07^{\mathrm{b}}$ & $5.23 \pm 0.04^{\mathrm{a}}$ & $4.88 \pm 0.04^{\mathrm{b}}$ \\
\hline Crude fibre & $2.80 \pm 0.04^{\mathrm{c}}$ & $2.87 \pm 0.00^{\mathrm{c}}$ & $3.33 \pm 0.04^{\mathrm{a}}$ & $3.08 \pm 0.06^{\mathrm{b}}$ & $2.89 \pm 0.05^{\mathrm{c}}$ & $2.09 \pm 0.06^{\mathrm{d}}$ \\
\hline Carbohydrate & $82.53 \pm 0.25^{\mathrm{a}}$ & $79.96 \pm 0.21^{\mathrm{b}}$ & $74.83 \pm 0.22^{\mathrm{c}}$ & $72.98 \pm 0.18^{c}$ & $69.12 \pm 0.10^{\mathrm{d}}$ & $80.19 \pm 0.11^{\mathrm{a}}$ \\
\hline
\end{tabular}

Values are means \pm SD of triplicate determination. Means in the same row with different superscript are significantly $(\mathrm{p}<0.05)$ different. Flour ratio $=$ sorghum: African yam bean: soybean.

Crude protein and fat contents ranged from 4.39-14.85\% and $3.70-5.23 \%$, respectively with the highest value recorded for SASD. Crude fibre ranged from 2.80-3.33\%. Carbohydrate content ranged from $69.12-82.53 \%$ for sample SASD and SG, respectively, sample SG was not significantly ( $>0.05)$ different from CTR (80.19\%). Energy value ranged from $377.70-382.95 \mathrm{kcal}$ with CTR having the highest value of $388.00 \%$.

\subsection{Mineral Composition of Complementary Flour Blends and Commercial Formula}

Table 3 shows the result of selected mineral composition in sorghum, African yam bean and soybean complementary flour blends and the commercial formula (cerelac). Significant $(\mathrm{p}<0.05)$ increases were observed in zinc, iron and magnesium contents as substitution level increased. It ranged from $3.55-5.80 \mathrm{mg} / 100 \mathrm{~g}, 46.00-85.60 \mathrm{mg} / 100 \mathrm{~g}$ and $9.85-14.30 \mathrm{mg} / 100 \mathrm{~g}$, respectively. Iron was the predominant mineral found in the blends and their values were higher than CTR. Calcium and sodium contents of blended samples were significantly $(\mathrm{p}<0.05)$ lower than CTR. It ranged from 20.45$45.30 \mathrm{mg} / 100 \mathrm{~g}$ and $40.50-45.60 \mathrm{mg} / 100 \mathrm{~g}$, respectively, with higher values found in SASD. CTR had the highest values for iron $(51.70 \mathrm{mg} / 100 \mathrm{~g})$ and magnesium $(11.30 \mathrm{mg} / 100 \mathrm{~g})$.

Table 3. Mineral composition ( $\mathrm{mg} / 100 \mathrm{~g}$ ) of complementary flour blends and commercial formula.

\begin{tabular}{|c|c|c|c|c|c|c|}
\hline \multirow{2}{*}{ Parameter } & SG & SASA & SASB & SASC & SASD & CTR \\
\hline & (100:0:0) & (90:5:5) & (80:10:10) & $(70: 15: 15)$ & $(60: 20: 20)$ & (Control) \\
\hline Zinc & $3.90 \pm 0.00^{\mathrm{d}}$ & $3.55 \pm 0.00^{\mathrm{e}}$ & $4.20 \pm 0.01^{\mathrm{c}}$ & $5.20 \pm 0.01^{b}$ & $5.80 \pm 0.01^{\mathrm{a}}$ & $2.10 \pm 0.01^{\mathrm{f}}$ \\
\hline Iron & $46.00 \pm 0.01^{\mathrm{f}}$ & $54.60 \pm 0.01^{\mathrm{e}}$ & $68.40 \pm 0.01^{\mathrm{d}}$ & $71.25 \pm 0.01^{\mathrm{c}}$ & $85.60 \pm 0.01^{\mathrm{a}}$ & $74.80 \pm 0.01^{b}$ \\
\hline Calcium & $25.70 \pm 0.07^{\mathrm{d}}$ & $20.45 \pm 0.07^{\mathrm{e}}$ & $20.55 \pm 0.07^{\mathrm{e}}$ & $42.60 \pm 0.07^{\mathrm{c}}$ & $45.30 \pm 0.07^{b}$ & $45.60 \pm 0.07^{\mathrm{a}}$ \\
\hline
\end{tabular}




\begin{tabular}{|c|c|c|c|c|c|c|}
\hline \multirow{2}{*}{ Parameter } & SG & SASA & SASB & SASC & SASD & CTR \\
\hline & (100:0:0) & $(90: 5: 5)$ & $(80: 10: 10)$ & $(70: 15: 15)$ & $(60: 20: 20)$ & (Control) \\
\hline Sodium & $40.65 \pm 0.07^{\mathrm{d}}$ & $40.50 \pm 0.07^{\mathrm{d}}$ & $40.60 \pm 0.07^{\mathrm{d}}$ & $41.30 \pm 0.07^{\mathrm{c}}$ & $45.60 \pm 0.07^{\mathrm{b}}$ & $51.70 \pm 0.07^{\mathrm{a}}$ \\
\hline Magnesium & $9.85 \pm 0.07^{\mathrm{e}}$ & $10.20 \pm 0.07^{\mathrm{d}}$ & $10.60 \pm 0.07^{\mathrm{c}}$ & $11.35 \pm 0.07^{\mathrm{b}}$ & $14.30 \pm 0.07^{\mathrm{a}}$ & $11.30 \pm 0.07^{\mathrm{b}}$ \\
\hline
\end{tabular}

Values are means \pm SD of triplicate determination. Means in the same row with different superscript are significantly $(\mathrm{p}<0.05)$ different. Flour ratio $=$ sorghum: African yam bean: soybean.

\subsection{Anti-nutrient Content of Complementary Flour Blends and Commercial Formula}

The result of anti-nutrient content of sorghum, African yam bean and soybean complementary flour blends and the commercial formula (cerelac) are presented in Table 4 . Significant $(p<0.05)$ reduction of oxalate, HCN and tannin contents were found in the blends as the substitution level increase. Oxalate was the highest mineral found in all the samples. It ranged from $87.79 \mathrm{mg} / 100 \mathrm{~g}$ (SASD) to $130.56 \mathrm{mg} / 100 \mathrm{~g}$ (SG), while CTR had the value of
$145.42 \mathrm{mg} / 100 \mathrm{~g}$. HCN content ranged from $1.26 \mathrm{mg} / 100 \mathrm{~g}$ for SASC to $2.27 \mathrm{mg} / 100 \mathrm{~g}$ for SASA, SASD had the lowest value and all blended samples were lower than CTR $(3.18 \mathrm{mg} / 100 \mathrm{~g})$. Tannin content ranged from $2.31 \mathrm{mg} / 100 \mathrm{~g}$ (SASD) to $3.29 \mathrm{mg} / 100 \mathrm{~g}$ (SASA). Phytate content was significantly $(\mathrm{p}<0.05)$ increased as the level of substitution increased. It ranged from $14.39 \mathrm{mg} / 100 \mathrm{~g}$ (SASA) to $23.61 \mathrm{mg} / 100 \mathrm{~g}$ (SASD), sample SASA had the lowest value and it was lower than the CTR having $19.64 \mathrm{mg} / 100 \mathrm{~g}$.

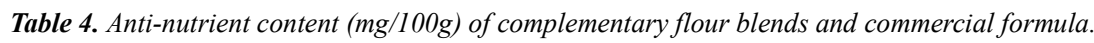

\begin{tabular}{lllllll}
\hline \multirow{2}{*}{ Parameter } & SG & SASA & SASB & SASC & SASD & CTR \\
\cline { 2 - 7 } & $\mathbf{( 1 0 0 : 0 : 0 )}$ & $\mathbf{( 9 0 : 5 : 5 )}$ & $\mathbf{( 8 0 : 1 0 : 1 0 )}$ & $\mathbf{( 7 0 : 1 5 : 1 5 )}$ & $\mathbf{( 6 0 : 2 0 : 2 0 )}$ & $($ Control) \\
\hline Oxalate & $130.56 \pm 6.37^{\mathrm{b}}$ & $121.55 \pm 6.37^{\mathrm{b}}$ & $105.35 \pm 3.82^{\mathrm{c}}$ & $96.79 \pm 3.18^{\mathrm{cd}}$ & $87.79 \pm 3.18^{\mathrm{d}}$ & $145.42 \pm 1.91^{\mathrm{a}}$ \\
Phytate & $21.35 \pm 0.00^{\mathrm{b}}$ & $14.39 \pm 0.00^{\mathrm{e}}$ & $15.28 \pm 0.00^{\mathrm{d}}$ & $17.83 \pm 0.00^{\mathrm{e}}$ & $23.61 \pm 0.00^{\mathrm{a}}$ & $19.64 \pm 0.00^{\mathrm{c}}$ \\
HCN & $2.06 \pm 0.01^{\mathrm{c}}$ & $2.27 \pm 0.01^{\mathrm{b}}$ & $1.83 \pm 0.01^{\mathrm{d}}$ & $1.26 \pm 0.00^{\mathrm{e}}$ & $0.58 \pm 0.00^{\mathrm{f}}$ & $3.18 \pm 0.00^{\mathrm{a}}$ \\
Tannin & $3.13 \pm 0.01^{\mathrm{b}}$ & $3.29 \pm 0.00^{\mathrm{a}}$ & $2.97 \pm 0.01^{\mathrm{c}}$ & $2.83 \pm 0.00^{\mathrm{d}}$ & $2.31 \pm 0.01^{\mathrm{e}}$ & $2.92 \pm 032^{\mathrm{c}}$ \\
\hline
\end{tabular}

Values are means $\pm \mathrm{SD}$ of triplicate determination. Means in the same row with different superscript are significantly $(\mathrm{p}<0.05)$ different. Flour ratio $=$ sorghum: African yam bean: soybean.

\subsection{Functional Properties of Complementary Flour Blends and Commercial Formula}

The result of functional properties of sorghum, African yam bean and soybean complementary flour blends and the commercial formula (cerelac) is presented in Table 5. The bulk density of the formulated samples was not significantly $(\mathrm{p}<0.05)$ different but higher than CTR. It ranged from $0.62 \mathrm{~g} / \mathrm{ml}$ for SASD to $0.70 \mathrm{~g} / \mathrm{ml}$ for SASA. Significant $(\mathrm{p}<0.05)$ differences existed among the formulated samples for water absorption and swelling capacities but lower than CTR. It ranged from 1.30$2.40 \mathrm{~g} / \mathrm{g}$ for SG and SASD, respectively, while the control had the highest value $(4.00 \mathrm{~g} / \mathrm{g})$. The oil absorption capacity of all samples showed no significant $(\mathrm{p}<0.05)$ difference, it ranged from $1.60-1.90 \mathrm{~g} / \mathrm{g}$ with SASA having the highest value while CTR had $1.80 \mathrm{~g} / \mathrm{g}$. The gelatinization temperature of the formulated samples was significantly $(\mathrm{p}<0.05)$ different from CTR, it ranged from $75.50^{\circ} \mathrm{C}$ (SASA) to $81.00^{\circ} \mathrm{C}$ (SASD) and CTR had $75.00^{\circ} \mathrm{C}$.

Table 5. Functional properties of complementary flour blends and commercial formula.

\begin{tabular}{|c|c|c|c|c|c|c|}
\hline \multirow{2}{*}{ Parameter } & SG & SASA & SASB & SASC & SASD & CTR \\
\hline & $(100: 0: 0)$ & $(90: 5: 5)$ & $(80: 10: 10)$ & $(70: 15: 15)$ & $(60: 20: 20)$ & (Control) \\
\hline Bulk density (g/ml) & $0.66 \pm 0.01^{\mathrm{a}}$ & $0.70 \pm 0.04^{\mathrm{a}}$ & $0.69 \pm 0.01^{\mathrm{a}}$ & $0.68 \pm 0.02^{\mathrm{a}}$ & $0.62 \pm 0.01^{\mathrm{ab}}$ & $0.55 \pm 0.02^{b}$ \\
\hline Water absorption capacity $(\mathrm{g} / \mathrm{g})$ & $1.30 \pm 0.14^{\mathrm{b}}$ & $1.40 \pm 0.00^{\mathrm{b}}$ & $1.90 \pm 0.71^{\mathrm{b}}$ & $1.90 \pm 0.71^{\mathrm{b}}$ & $2.40 \pm 0.00^{\mathrm{ab}}$ & $4.00 \pm 0.00^{\mathrm{a}}$ \\
\hline Oil absorption capacity $(\mathrm{g} / \mathrm{g})$ & $1.80 \pm 0.00^{\mathrm{a}}$ & $1.90 \pm 0.14^{\mathrm{a}}$ & $1.60 \pm 0.00^{\mathrm{a}}$ & $1.70 \pm 0.14^{\mathrm{a}}$ & $1.80 \pm 0.00^{\mathrm{a}}$ & $1.80 \pm 0.00^{\mathrm{a}}$ \\
\hline Swelling capacity $(\mathrm{ml} / \mathrm{ml})$ & $1.00 \pm 0.00^{\mathrm{b}}$ & $1.00 \pm 0.00^{\mathrm{b}}$ & $1.10 \pm 0.00^{\mathrm{b}}$ & $1.00 \pm 0.00^{\mathrm{b}}$ & $1.00 \pm 0.00^{\mathrm{b}}$ & $2.00 \pm 0.00^{\mathrm{a}}$ \\
\hline Gelling temperature $\left({ }^{\circ} \mathrm{C}\right)$ & $79.00 \pm 0.00^{\mathrm{b}}$ & $75.50 \pm 0.71^{\mathrm{c}}$ & $78.50 \pm 0.71^{\mathrm{b}}$ & $80.00 \pm 0.00^{\mathrm{ab}}$ & $81.00 \pm 0.00^{\mathrm{a}}$ & $75.00 \pm 0.00^{\mathrm{c}}$ \\
\hline
\end{tabular}

Values are means $\pm \mathrm{SD}$ of triplicate determination. Means in the same row with different superscript are significantly $(\mathrm{p}<0.05)$ different. Flour ratio $=$ sorghum: African yam bean: soybean.

\subsection{Sensory Evaluation of Complementary Flour Blends and Commercial Formula}

Appearance, taste, flavour, mouth feel and general acceptability level of the formulated samples and CTR showed significant $(p<0.05)$ difference (Table 6). The appearance and taste ranged from 6.80-6.95 and 6.05-7.20, respectively, with CTR having the highest score of 7.50 for appearance and 7.35 for taste. The flavour ranged from 5.95
(SASD) to 7.20 (SG) with the CTR and SG having the highest score of 7.20. The mouth feel ranged from 6.05-7.25, CTR had the highest score of 7.30. The consistency levels of $\mathrm{SG}$ and CTR were not differed significantly $(\mathrm{p}>0.05)$, it ranged from 4.80-7.00 for sample SG with CTR and SG having the highest score (7.00). CTR was generally accepted with highest score of 8.05 while the formulated samples ranged from 6.70 for sample SASC to 7.20 for sample SG. 
Table 6. Sensory evaluation of reconstituted complementary flour blends and commercial formula.

\begin{tabular}{|c|c|c|c|c|c|c|}
\hline \multirow{2}{*}{ Parameter } & SG & SASA & SASB & SASC & SASD & CTR \\
\hline & $(100: 0: 0)$ & $(90: 5: 5)$ & $(80: 10: 10)$ & $(70: 15: 15)$ & $(60: 20: 20)$ & (Control) \\
\hline Appearance & $6.85 \pm 1.73^{\mathrm{b}}$ & $6.95 \pm 1.73^{b}$ & $6.80 \pm 1.67^{b}$ & $6.85 \pm 1.38^{b}$ & $6.85 \pm 1.49^{b}$ & $7.50 \pm 1.43^{\mathrm{a}}$ \\
\hline Taste & $6.55 \pm 1.504^{b}$ & $7.20 \pm 0.95^{\mathrm{a}}$ & $6.05 \pm 2.16^{\mathrm{b}}$ & $6.10 \pm 1.48^{b}$ & $6.40 \pm 1.88^{b}$ & $7.35 \pm 1.87^{\mathrm{a}}$ \\
\hline Flavour & $7.20 \pm 1.361^{\mathrm{a}}$ & $7.05 \pm 1.28^{\mathrm{a}}$ & $6.60 \pm 1.57^{b}$ & $6.60 \pm 1.35^{\mathrm{b}}$ & $5.95 \pm 1.47^{\mathrm{c}}$ & $7.20 \pm 1.28^{\mathrm{a}}$ \\
\hline Mouth feel & $7.25 \pm 0.910^{\mathrm{a}}$ & $7.05 \pm 1.54^{\mathrm{a}}$ & $6.60 \pm 1.70^{\mathrm{b}}$ & $6.25 \pm 1.74^{\mathrm{b}}$ & $6.05 \pm 1.57^{b}$ & $7.30 \pm 1.53^{\mathrm{a}}$ \\
\hline Consistency & $7.00 \pm 1.38^{\mathrm{a}}$ & $6.70 \pm 1.49^{\mathrm{b}}$ & $6.30 \pm 2.03^{\mathrm{ab}}$ & $5.90 \pm 1.99^{\mathrm{ab}}$ & $4.80 \pm 2.24^{\mathrm{c}}$ & $7.00 \pm 1.26^{\mathrm{a}}$ \\
\hline Gen. acceptability & $7.20 \pm 1.99^{b}$ & $6.90 \pm 1.86^{\mathrm{b}}$ & $6.75 \pm 2.02^{\mathrm{c}}$ & $6.70 \pm 1.38^{\mathrm{c}}$ & $6.75 \pm 1.68^{\mathrm{c}}$ & $8.05 \pm 0.95^{\mathrm{a}}$ \\
\hline
\end{tabular}

Values are means \pm SD of triplicate determination. Means in the same row with different superscript are significantly $(\mathrm{p}<0.05$ ) different. Flour ratio $=$ sorghum: African yam bean: soybean.

\section{Discussion}

\subsection{Proximate Composition and Energy Value Complementary Flour Blends and Commercial Formula}

Moisture content of the samples was within the acceptable limit for long term storage of flour. Studies have shown that low moisture content in food products will prevent the growth of mould and reduce moisture dependent biochemical reactions [18] and therefore enhance the storage stability of the flour. Ash values obtained was within range compared with $2.08-4.13 \%$ as reported [19] but higher than the ash content $(0.56-2.00 \%)$ of complementary food formulated from fermented maize, soybean and carrot flours reported [11]. The ash content of a food material could be used as an index of mineral constituents of the food [20]. The result of crude protein is within the range (9-22\%) of complementary foods from rice, unsprouted/sprouted green gram and apple pulp flour blends reported [21]. Values obtained were lower than the values reported [22] for fermented and roasted sorghum and soybean flour blends. Crude fat content of the formulated samples were higher than $7.00-16.35 \%$ as reported [23] for soy-sorghum-roselle complementary food. Fat is important in the diets of infants and young children as it provides high energy density and facilitates the absorption of fat soluble vitamins. It also provides essential fatty acids such as omega-3 and omega-6 polyunsaturated fatty acids (PUFA) needed for proper neural development in infants and young children [1]. Low fat is beneficial as it ensures long product shelf life by reducing susceptibility to oxidative rancidity. Crude fibre is one of the non-energy yielding nutrients; it helps to increase the nitrogen utilization and absorption of some micronutrients [24]. The crude fibre was within the range similar to $0.20-4.40 \%$ as reported [25] using malted pre-gelatinized maize, soybean and carrot flour. The high carbohydrate contents observed in this study are nutritionally desirable as children require energy to carry out their rigorous physical and physiological activities as growth continues [26]. Carbohydrate content decreased as amount of supplementation increased, this is in agreement with the work [27]. Energy values obtained are within the range $363.86-442.46 \mathrm{kcal}$ reported by [28] using sprouted paddy rice, sprouted African yam bean and pawpaw.

\subsection{Mineral Content of Complementary Flour Blends and Commercial Formula}

Zinc value increased with increasing soybean and African yam bean supplementation. Samples had values higher than values reported [29, 30]. Iron values were higher than $2.98-4.38 \mathrm{mg} / 100 \mathrm{~g}$ as reported [31] using sorghum and African yam bean. This is in line with the report that African yam bean has high iron content [28]. Iron is essential for the formation of blood cells and prevention of anaemia in infants and children. Calcium level was higher than the value $(10.52-39.16 \mathrm{mg} / 100 \mathrm{~g})$ reported [32] using African yam bean-carrot flours. It was also higher than $15.01-25.10 \mathrm{mg} / 100 \mathrm{~g}$ as reported [33] using malted millet, plantain and soybean. Sodium level is higher than $6.95-8.57 \mathrm{mg} / 100 \mathrm{~g}$ as reported [10] using maize, African yam bean and pigeon pea. It is essential in the regulation of water content and in the maintenance of osmotic pressure of the body fluid. It also aids in the transport of $\mathrm{CO}_{2}$ in the blood. Magnesium level was higher than $2.08-4.88 \mathrm{mg} / 100 \mathrm{~g}$ as reported [31]. Its level increased with increasing level of soybean and African yam bean supplementation which is in line with [34] who reported that African yam bean is a rich source of magnesium. It helps in the relaxation of nerves and muscle essential for the formation of bone and clotting of the blood.

\subsection{Anti-nutrient Content of Complementary Flour Blends and Commercial Formula}

Oxalate binds with calcium and iron and causes these minerals to crystalize and thus the body cannot properly utilize the calcium and iron. High level of phytate limits the bioavailability and hence utilization of minerals, specifically calcium, magnesium, iron and manganese by forming insoluble compounds that are indigestible. Similar result $(1.84-2.67 \mathrm{mg} / 100 \mathrm{~g})$ was reported by [35] in evaluating complementary food formulated from local staples using sorghum, soybean and plantain flour. Tannins are known to bind protein including digestive enzymes leading to poor protein digestibility. The tannin level for this study was within the range of 2.55$2.85 \mathrm{mg} / 100 \mathrm{~g}$ as recorded by [35] for complementary foods based produce from soybean, sorghum and sweet potatoes flour blends. 


\subsection{Functional Properties of Complementary Flour Blends and Commercial Formula}

The bulk density of the formulated complementary flour blends was low. Sprouting of African yam bean must have contributed to low bulk density. Similar finding was reported by [37] of $0.60-0.67 \mathrm{~g} / \mathrm{ml}$ for pearl millet and germinated pigeon pea flour blends, as germination has been reported to be useful in preparation of low bulk foods for infants [38]. Low bulk density values of the complementary food samples imply that more of the samples could be prepared using a small amount of water yet give the desired energy nutrient density. The low water absorption capacity (WAC) of formulated samples may have resulted from the inclusion of sprouted grains/seed flours owing to the fact that starch degradation during germination affects starch granules which affect the level of water the available starch is able to hold. Such low WAC values are desirable for making thinner gruels [28]. It also results in increasing the energy and nutrient-density of the infant foods, a very important aspect in complementary feeding. Oil absorption capacity is an important functional property as the ability of flours to absorb and retain oil may enhance flavour retention and improve mouth feel [39]. Complementary foods do not require high swelling capacity as the food would absorb more water and have less solid resulting in low nutrient density for infants [40]. High temperature presented in this study could have been due to a reduced starch content of the flours which may have occurred during sprouting. The same trend was observed by [41] who had increase temperature with increased level of substitution.

\subsection{Sensory Evaluation of Complementary Flour Blends and Commercial Formula}

Appearance is very important as a sensory property which contributes to acceptability and choice of food [28]. Appearance of complementary food formulations in addition to a sufficient energy density correspond to food preferences for infants and young children and are of prime importance. Taste is a parameter for accessing sensory attributes in food; it is a very important property. In this case it would stimulate the child's likeness and acceptance for the food. Indeed, even if a product is appealing and meets nutrient requirements without good taste, the product would likely not be acceptable. The mouth feel is very important in a complementary food as it will determine the amount of food an infant would consume since they can only swallow a smooth gruel not a coarse one. The panels' range of likeness for all the attributes were within 'dislike slightly' to 'neither like nor dislike', this could be attributed to the beany flavour of African yam bean and soybean. SG (Sorghum flour) was generally accepted more than other formulated samples; the difference could be attributed to the unique quality of sorghum flour in preparation of complementary food [42].

\section{Conclusion}

Sorghum, African yam bean and soybean are locally available and affordable raw materials that can be used by mothers as home-based complementary foods. There was increase in the nutrient content of the formulated blends that can meet recommended level of protein, energy and other nutrients. SASD with the highest African yam bean and soybean substitution had the highest crude protein, crude fat and energy level contents with highest mineral contents and lowest antinutrient contents. The complementary flour blends had also shown desirable level of functionality with respect to bulk density, water absorption, swelling and gelling temperature.

\section{References}

[1] Igyor M., P. Yusufu and I. A. Sengev (2011). Evaluation of Physicochemical, Functional and Sensory Properties of Fermented Fura Powder Supplemented with Soy. Nigerian Food Journal 28, 113-121.

[2] Alawode, E. K., M. A. Idowu, A. A., Adeola, E. K. Oke and S. A. Omoniyi (2017). Some Quality Attributes Of Complementary Food Produced From Flour Blends of Orange Flesh Sweetpotato, Sorghum, and Soybean. Croat. J. Food Sci. Technol. 9 (2), 122-129.

[3] Bolarinwa, I., J. O. Olajide, M. O. Oke, S. A. Olaniyan and F. O. Grace (2016). Production and Quality Evaluation of Complementary Food from Malted Millet, Plantain and Soybean Blends. International Journal of Scientific and Engineering Research 7 (5), 663-674.

[4] Usman, M. A., M. K. Bolade and J. Samaila (2016). Functional Properties of Weaning Food Blends from Selected Sorghum (Sorghum bicolor (L.) Moench) Varieties and Soybean (Glycine max). African Journal of Food Science 10 (8), 112-121.

[5] O. S. Eke (2002). Effects of Malting on the Dehulling Characteristics of African Yam Bean (Sphenostylis Stenocarpa) Seeds and the Functional Properties of the Flour. Journal of Food Science and Technology 39 (4), 406-409.

[6] Onyenekwe, P., Amah, D. and P. Njoku (2000). Effect of Cowpea Processing Method on Flatulence Causing Oligosaccharide. Nutritional Research 20, 349-358.

[7] Adewale, B., Aremu, C. and A. Daniel (2012). The Nutritional Potentials and Possibilities in African Yam Beans For Africa. International Journal of Agricultural Science, 3 (1): 8-19.

[8] P. Akubor (2008). Evaluation of Physiochemical and Sensory Properties of Soybean-Sweet Potato Supplementary Food. Journal of Chemical Society of Nigeria 33.

[9] Adepeju, A., O. Abiodun, A. Dauda and A. Fatiregun (2016). Nutritional Evaluation of Weaning Food Prepared from Fermented Sorghum, Germinated Soybean and Defatted Sesame Seed. FUTA Journal of Research in Sciences 12 (2), 260-269.

[10] Oludumila, O. and V. Enujiugha (2017). Physiochemical and Rheological Properties of Complementary Diet from Blends of Maize, African Yam Bean and Pigeon Pea Flour. Science Journal of Food Science and Nutrition 3 (1), 005-011. 
[11] Barber, L., P. Obinna-Echem and E. Ogburia (2017). Proximate Composition Micronutrient And Sensory Properties Of Complementary Food Formulated From Fermented Maize, Soybeans and Carrot Flours. Sky Journal of Food Science 6 (3), 033-039.

[12] AOAC (2005). Official Methods of Analysis of the Association of Official Analytical Chemists. 17th Ed. chapter 50, 18 and Chapter, 4. VA, USA.

[13] Onwuka G. I. (2005). Food Analysis and Instrumentation: Theory and Practice, Lagos, Nigeria: Naphtali Prints Nigeria, $1-19$.

[14] Aina, V., S. Banita, Z. Amina, H. Hauwa, U. Hauwa, R. Akinboboye, and A. Mohammed (2012). Determination of Nutritional and Anti-nutritional Content of Vitis vinifera (Grapes) Grown In Bomo (Area C) Zaria, Nigeria. Advance Journal of Food Science and Technology 4 (6), 445-448.

[15] Doss, A., M. Pugalenthi, V. Vadivel, G. Subhashini and R. Subash (2011). Effect of Processing Technique on the Nutritional Composition of Under-Utilize Food Legume Canavalia ensiformis L. International Food Research Journal 18 (3), 965-970.

[16] Abbey, B. and G. Ibeh, (1988). Functional Properties of Raw and Heat Processed Cowpea (Vigna unguiculata, Walp) Flour. Journal of Food Science 53 (6), 1775-1778.

[17] Ihekoronye, A. I. and P. O. Ngoddy (1985). Integrated Food Science and Technology for the Tropics. Macmillan Publishers Ltd., London, pp: 109.

[18] Omimawo, I. A. and P. I. Akubor (2012). Food Chemistry (Integrated Approach with Biochemical Background). 2nd Edition. Joytal Printing Press, Agbowo, Ibadan, Nigeria.

[19] Okoye, J. I. and G. I. Ene (2018). Evaluation of Nutritional and Organoleptic Properties of Maize-Based Complementary Foods Supplemented with Black Bean and Crayfish Flours. Global Advanced Research Journal of Food Science and Technology 6 (1), 001-009.

[20] Fusuan, T. O., S. O. Fawale, D. E. Enwerem, N. Uche and E. A. Ayodele (2017). Physicochemical, Functional and Economic Analysis of Complementary Food from Cereal, Oil Seed and Animal Polypeptide. International Food Research Journal 24 (1), 275-283.

[21] Bazaz, R., N. B. Waqas and F. A. Masoodi (2016). Development and Quality Evaluation of Hypoallergic Complementary Foods from Rice Incorporated with Sprouted Green Gram Flour. Cogent Food \& Agriculture 2, 1154714.

[22] Msheliza, E. A., J. B. Hussein, J. O. Y. Ilesanmi and I. Nkama (2018). Effect of Fermentation and Roasting on the Physicochemical Properties of Weaning Food Produced from Blends of Sorghum and Soybean. J. Nutr. Food Sci. 8, 2.

[23] Adedeji, O. E., D. E. Jegede, K. O. Abdulsalam, U. E. Umeohia, O. A. Ajayi and J. E. Iboyi (2015). Effect of Processing Treatments on the Proximate, Functional and Sensory Properties of Soy-Sorghum-Roselle Complementary Food. British Journal of Applied Science \& Technology 6 (6), 635-643.

[24] Michaelsen, K. F., L. Weaver, F. Branca and A. Robertson (2000). Feeding and Nutrition Of Infants And Young Children-Guidelines for the WHO European Region, with Emphasis on The Former Soviet Countries. WHO Regional Publications, European Series 87, 45-80.
[25] Obinna-Echem, P., L. Barber and C. Enyi (2018). Proximate Composition and Sensory Properties of Complementary Food Formulated from Pre-Gelatinized Maize, Soybean and Carrot Flours. Journal of Food Research 7 (2), 17-24.

[26] Ibironke, S. I., J. B. Fashakin and O. A. Badmus (2012). Nutritional Evaluation of Complementary Food Developed from Plant and Animal Sources. Nutrition and Food Science $42(2), 111-120$.

[27] Adeola, A. A., O. M. Solola, O. Apata, and E. R. Ohizua (2017). Assessment of Some Attributes of Unripe Cooking Banana (Cardaba musa ABB), Pigeon Pea (Cajanus cajan) and orange fleshed sweet potato (Ipomoea batatas) Flour Blends for Use as Complementary Feeding. Croat. J. Food Sci. Technology 9 (2), 122-129.

[28] Obasi, N. E., Ukah, O. G. and C. J. Okakpu (2018). Formulation and Evaluation of Complementary foods from flour blends of sprouted paddy rice (Oryza sativa), sprouted African yam bean (Sphenostylis sternocarpa) and pawpaw fruit (Carica papaya). Advances in Research, 15 (5): 1-18.

[29] Omah. E. C. E. C. Umego, P. C. Onah and D. A. Onu (2017). Evaluation of Complementary Foods from Blends of Roasted Rice and Soybean Flours, Innovare Journal of Food Sciences 5 (4), 20-24.

[30] Kiin-Kabari, D. B., M. O. Akusu and A. G. OsemeneOnwochei (2019). Micronutrient Composition and Its BioAvailability in Complementary Foods Developed from Cereal (Millet/Maize), Soybean and Monkey Kola Flours. International Journal of Food and Nutrition Research 2, 24.

[31] Okoye, J. I., G. I. Ene and C. C. Ojobor (2017). Chemical Composition and Functional Properties of Sorghum-African Yam Bean Flour Blends. Sky Journal of Food Science 6 (2), 021-026.

[32] Kukwa, R. E., P. E. Okpainya and J. K. Ikya (2018). Micronutrients in African Yam Bean-Carrot Flours and Acceptability of Its Gruels for Complementary Food. Asian Food Science Journal 4 (2), 1-9.

[33] Bolarinwa, I. F., S. A Olaniyan, L. O. Adebayo and A. A. Ademola (2015). Malted Sorghum-Soy Composite Flour: Preparation, Chemical and Physico-Chemical Properties Malted sorghum-Soy Composite Flour: Preparation, Chemical and Physico-Chemical Properties. J. Food Process Technol. 6, 467.

[34] Obatolu, V. A, S. B. Fasoyiro and I. O. Ogunsunmi (2007). Processing and Functional Properties of African Yam Bean (Sphenostylis stenocarpa). Journal of Food Processing and Preservation 31, 240- 249.

[35] Onoja, U., P. Akubor, D. Gernar and C. Chinmma (2014). Evaluation of Complementary Food From Formulated from Local Staples and Fortified with Calcium, Iron and Zinc. Journal of Nutrition and Food Science 4, 326.

[36] Obiakor-Okeke, P., J. A. Amadi and J. Chikwendu (2014). Development and Evaluation of Complementary Foods Based on Soyabean, Sorghum and Sweet Potatoes Flour Blends. Food Science and Quality Management33, 77-86.

[37] Sodipo, M. A., O. M. Lawal, O. E. Alabi, O. O. Solomon, M. O. Oluwamukomi, and I. B. Oluwalana (2018). Physicochemical Properties and Amino Acid Profile of Extruded Products from Pearl Millet and Germinated Pigeon Pea. Annals. Food Science and Technology 2, 183-190. 
[38] Bello, F. A., I. I. Udo and D. L. Mbak (2017). Proximate Composition and Functional Properties of Sprouted Sorghum (Sorghum bicolor) and Defatted Fluted Pumpkin Seed (Telfairia occidentalis) Flour Blends. American Journal of Innovative Research and Applied Sciences 5 (4), 254-259.

[39] Kaur, M., P. Kaushal and K. S. Sandhu (2019). Studies on Physicochemical and Pasting Properties of Taro (Colocasia esculenta L.) Flour in Comparison with a Cereal, Tuber and Legume Flour. Journal of Food Science and Technology 50 (1), 94-100.

[40] Ojinnaka, M., F. Anyanwu and A. Ihemeje (2013). Nutritional Evaluation of Cookies Produced from African Breadfruit
(Treculia africana) Starch and Wheat Flour. International Journal of Agriculture and Food Science 3, 95-99.

[41] Chandra, S., S. Samsher and K. Durvesh (2015). Evaluation of Functional Properties of Biscuits from Green Gram, Wheat and Potato Composite Flours and their Sensorial Attributes. J. Food Sci. Technol. 52 (6), 3681-3688.

[42] Thaoge, M., M. Adams, M. Sibra, T. Watson, J. Taylor and E. Goyaverts (2003). Production of Improved Infant Porridges from Pearl Millet Using A Lactic Acid Fermentation Step and Addition of Sorghum Malt to Reduce Viscosity of Porridges With High Protein, Energy and Solids (3\%) Content. World Journal of Microbiology and Biotechnology 19, 305-310. 